\title{
Screening of promising selection samples of alfalfa variable in productivity and longevity
}

\author{
M. A. Tormozin*, A. A. Zyryantseva \\ Federal State Budgetary Scientific Institution «Ural Federal Agrarian Scientific Research \\ Centre, Ural Branch of the Russian Academy of Science» \\ Russian Federation
}

\begin{abstract}
The article presents the results of studying the numbers of alfalfa variable in breeding nursery (20112019 and 2015-2019) on the complex of economically valuable traits. High winter resistance of all varieties was revealed. On average, for three years in the breeding nursery the establishment of 2015-2019 years significantly exceeded the standard number on the seed yield: Victoria - by 70\%, CHP-1 - 84\%, CHP-2 - 24\%, $192-92$ (f) $41 \%, 213-11-74 \%$. For three years of testing all these promising numbers significantly exceeded the Sarga variety (standard) in seeds yield. On average for three years the yield of green mass was $5.0-20.1 \mathrm{~kg} / 10 \mathrm{~m}^{2}$. According to this indicator the following samples significantly exceed the standard: Victoria - by $20.4 \%$, 213-11 $-\mathbf{5 . 1 \%}, \mathbf{1 9 9 - 0 6}-\mathbf{1 5 . 0 \%}$. Dry matter collection was $1.08-4.27 \mathrm{~kg} / 10 \mathrm{~m}^{2}$ (standard $3.78 \mathrm{~kg} / 10 \mathrm{~m}^{2}$ ), excess of 4.5 $13.0 \%$. During the longevity test in the breeding nursery of alfalfa (sowed in 2011) the following data was obtained: the seeds yield of breeding numbers in 2019 was 50.0 $333.3 \mathrm{~g}$ from $10 \mathrm{~m}^{2}$. The highest yield was noted in numbers: 20-89N (st), 203-06, 197-06/1, 27-86 (f), 199-06/1, 101-2 (st), 20-89N (st).
\end{abstract}

Key words - alfalfa, variety, breeding, winter resistance, dry substance, seed yield.

\section{INTRODUCTION}

Oper URRENTLY, alfalfa occupies the largest area of perennial legumes in the world — about 30 million hectares [1]. So is in the Sverdlovsk region, where the acreage of perennial grass in 2019 amounted to 302,012 hectares, including the increased area of alfalfa to 25,187 hectares - compared to 2006, when the area occupied by alfalfa was 6,660 hectares - an increase of almost four times. It is associated with the high milk productivity of the region, alfalfa is the undisputed leader in the content of exchange energy, amino acid and fractional composition of feed.

In countries with developed animal husbandry, perennial grass occupies up to $70-75 \%$ of the total area of fodder crops, which is explained by the fact that the foods made from perennial grass are the most nutritious, full, cheap and well digested by animals [2].
Of the perennial species of alfalfa in the non-chernozem zone, the greatest interest is alfalfa variable or bastard lucerne (Medicago sativa x M. varia), which occurred as a result of natural or artificial crossing of creeping alfalfa (M. sativa L.), yellow (M. falcata L.) and northern (M. borealis G.). Depending on ecological-geographical origin, nature of hybridity and biological features alfalfa variable is divided into three groups of varietal types: motley hybrid, yellow hybrid and blue hybrid [3].

The type is characterized by high ecological ductility; has higher winter resistance compared to creeping alfalfa, therefore it has more perspective for territories with extreme environmental conditions.

It is noted that the mass yield, power and nature of vegetative growth, as well as height of plants in the second year of life there is a greater genetic dispersion than in the year of sowing [4]. Therefore, the selection of plants in the second year of life should be more effective [5].

It was established that the vegetative productivity of alfalfa is more determined by the number of stems in the plant. rather than by the mass of one stem, and the seed is the result of the influence of the number of tied beans on the plant and seed productivity of one stem [5], [6].

Creation of pure-breeding set for such strict outbreeds as alfalfa and other types of fodder cultures is practically impossible. Yet it is possible to create phenotype balanced micropopulations as components for synthetic varieties [7] [9]. With this, the population will be more resistant with longterm evaluation and sampling.

The purpose of the work is to identify promising material at all stages of the breeding process, as well as to carry out a long-term evaluation of new varieties of alfalfa variable in the complex of economic and value-added features.

\section{MATERIALS AND METHODS}

The research was carried out in 2011-2019 in the Department of Breeding and Seed Breeding of Perennial Herbs of the Ural Research Institute of Agriculture - a branch of the Federal state budgetary institution of the Ural Federal Agrarian Scientific and Research Center, the Ural Branch of the Russian Academy of Sciences within the framework of the State assignment in the direction of "Fundamental bases of breeding process management of new plants genotypes creation with high economic and valuable 
signs of productivity, resistance to bio- and abiostressors" on the topic "Development, improvement of new methods of breeding work, creation of initial material and new varieties of spring and winter grain, legumes, fodder crops and potatoes".

In breeding nursery of alfalfa (2011 sowing), there was an offspring estimation of selected biotypes in wide-row sowing, consisting of 43 numbers, taking place; those were the selection of the Ural Research Institute of Agriculture branch of the Federal state budgetary institution of the Ural Federal Agrarian Scientific and Research Center, the Ural Branch of the Russian Academy of Sciences, standard Uralochka variety. It consisted of 10 plants of each population selected in the field according to seed productivity, which were dug out and transplanted into vessels on the plants accelerated vegetation skids (PAVS) in a winter greenhouse in autumn of 2007. In its study, the ability to tie seeds in the field conditions and with complete isolation (greenhouse) were assessed. The best self-fertile genotypes were multiplied and planted by stalks in field conditions.

In the breeding nursery (2015 sowing), productivity assessment is also carried out with wide-row sowing, the nursery includes 56 numbers, standard - Sarga. The composition of the nursery includes three complex hybrid populations; those are selected and formed according to morphological characteristics, three blocks on the color of the corolla: blue, yellow- and motley hybrid populations.

There are genetic studies [7] - [9], which revealed, for example, that the purple color of a flower is caused by anthocyanin dissolved in cell juice, the production of which is controlled by two complementary genes through the enzymatic system of the plant. In the absence of one of the genes, the flowers turn out to be white. Yellow color is caused by two different pigments - anthocyanin and carotene in plastides, which act under the control of several genes.

Parent forms were local population varieties, as well as the best populations from the collection nursery.

Sowing is summer wide-row achlamydeous, seeding rate 9 million germinating seeds per 1 ha. The accounting area of the plot is 2.4 and $3.6 \mathrm{~m}^{2}$, the repeatability is four and six times when estimating the numbers for seed productivity and twice - when estimating the feed productivity, leafage, nutritional value. Field experiments, records, observations and assessments were carried out in accordance with generally accepted guidelines [10]. Statistical processing of experimental data - by the method of dispersion analysis of Dospekhov B.A. [11].

The main climatic indicators of the region: the sum of effective temperatures above $5^{\circ} \mathrm{C}-1282^{\circ} \mathrm{C}$, while during the years of research (2011-2019) the fluctuations amounted to $1324-1906^{\circ} \mathrm{C}$, more than $10^{\circ} \mathrm{C}-557^{\circ} \mathrm{C}$, during the study 598.5-960 ${ }^{\circ} \mathrm{C}, 15{ }^{\circ} \mathrm{C}-115{ }^{\circ} \mathrm{C}$, changes $115-418{ }^{\circ} \mathrm{C}$. Longterm total precipitation for periods with given temperatures is 330, 263 and $161 \mathrm{~mm}$. During the study for similar periods the changes were as follows: $246-464 \mathrm{~mm}, 132-425 \mathrm{~mm}, 94-235$ $\mathrm{mm}$. The sum of positive temperatures for the growing period is $2090{ }^{\circ} \mathrm{C}$, deviations from the multi-year indicator were 2026-2804 ${ }^{\circ} \mathrm{C}[12]-[14]$.

\section{RESULTS AND DISCUSSION}

It is believed that the period of economic use of alfalfa grass is limited to 4-5 years [15]. Other studies performed in All-Russia Scientific Research Institute of fodder, RSAUMAA named after K.A. Timiryazev, show that productive longevity of alfalfa can reach 13 years or more [16], [17].

The interest in alfalfa longevity from the seed productivity point of view is that several researchers in Moscow and Yaroslavl regions estimate productive longevity of plants formation from number of mowing, botanical composition, fertilizers, binary sowing with cereals or legumes (for example, birds-foot trefoil). Besides, the study carried out in the USA showed that the yield of alfalfa starts to decrease if the density per $1 \mathrm{~m}^{2}$ is less than 32-54 plants, and the normal grass stand density to obtain good yield is 600 shoots per $1 \mathrm{~m}^{2}$ [18], [19].

The aim of our research is to assess the productive alfalfa longevity in its pure form, with wide-row sowing, seedproduction sowing.

Longevity researches are widely used in the selection programs of DLF TRIFOLIUM (Dutch seed company), for example, they have created Saskia - synthetic variety consisting of 59 clones, sampled from the field with 8-year old grass stand in the region with long cold winters.

Only thanks to evaluation of perspective samples (in terms of longevity) in breeding nurseries it is possible ti distinguish winter-resistant and grass stand resistant biotypes.

In addition, low fertility is a particular problem of alfalfa. Improvement of this indicator is complicated by a large number of factors, both external and internal, biological, genetically controlled. Such as the features of the plant itself, the presence of pollinators insects, environmental conditions and its interaction [20]-[22].

Biotypes forming a high percentage of seed formation in conditions of excessive humidification and heat deficiency have been obtained, in which autotripping occurs at the temperature of the air not reaching the required level for alfalfa of $26-30^{\circ} \mathrm{C}$.

In 2012, for the second year of life, the yield of seeds was 69.4-233.3 g/10 $\mathrm{m}^{2}$. Reliable exceeding over the Uralochka standard was provided by numbers: $213-11-$ by $17.4 \%(+$ $\left.30.5 \mathrm{~g} / 10 \mathrm{~m}^{2}\right), 203-06 / 1-23.8 \%\left(+41.6 \mathrm{~g} / 10 \mathrm{~m}^{2}\right), 213-11 / 1$ $-33.3 \%\left(+58.3 \mathrm{~g} / 10 \mathrm{~m}^{2}\right)$ (Table 1).

In the third year of life (2013), the seed yield of experimental genotypes ranged from $47.7 \mathrm{~g} / 10 \mathrm{~m}^{2}$ to 248.6 $\mathrm{g} / 10 \mathrm{~m}^{2}$. Reliable excess over Uralochka standard was provided by numbers: $199-06 / 2-241.6 \mathrm{~g} / 10 \mathrm{~m}^{2}(+59.7 \mathrm{~g} / 10$ $\left.\mathrm{m}^{2}\right), 204-06 / 1-247.2 \mathrm{~g} / 10 \mathrm{~m}^{2}\left(+65.3 \mathrm{~g} / 10 \mathrm{~m}^{2}\right), 203-06 / 2-$ $248.6 \mathrm{~g} / 10 \mathrm{~m}^{2}\left(+66.7 \mathrm{~m}^{2}\right)$.

In 2014, on September 7th (7 days earlier than usual), there was a decrease in the average daily temperature of $+10{ }^{\circ} \mathrm{C}$ towards declination. In addition, the growing season of 2014 was characterized by late spring, cool with intense rainfall in summer, a small number of pollinator insects. Due to the weather conditions occurred in 2014 , we were unable to harvest the seeds. 
Table 1. Yield of alfalfa seeds variable in breeding nursery, g from $10 \mathrm{~m}^{2}$, (sowing in 2011, accounting 2012-2019*)

\begin{tabular}{|c|c|c|c|c|c|c|c|}
\hline \multirow[t]{2}{*}{ Genotype } & \multicolumn{5}{|c|}{ Year of life } & \multirow{2}{*}{$\overline{\mathrm{x}}$} & \multirow[t]{2}{*}{$\%$ to st } \\
\hline & 2nd & $3 \mathrm{rd}$ & 5 th & 6th & 9th & & \\
\hline Uralochka (b) - (st.) & 175.0 & 181.9 & 52.8 & 125.0 & 116.6 & 130.3 & 100 \\
\hline $20-89 \mathrm{~N}(\mathrm{st})$ & 69.4 & 77.7 & 63.8 & 175.0 & 156.3 & 108.4 & 83 \\
\hline $199-06 / 2$ & 147.2 & 241.6 & 79.2 & 248.6 & 333.3 & 210.0 & 161 \\
\hline $101-2$ (st) & 80.5 & 152.7 & 47.2 & 194.4 & 177.1 & 130.4 & 100 \\
\hline $203-06 / 2$ & 88.8 & 122.2 & 30.5 & 138.8 & 110.4 & 98.1 & 75 \\
\hline 203-06 & 100.0 & 138.8 & 58.3 & 147.2 & 175.0 & 123.9 & 95 \\
\hline $204-06 / 1$ & 131.1 & 247.2 & 75.0 & 209.7 & 133.3 & 159.3 & 122 \\
\hline Uralochka (st) & 166.6 & 97.2 & 31.9 & 84.7 & 122.9 & 100.7 & 77 \\
\hline Uralochka (f) & 187.5 & 198.6 & 69.4 & 177.7 & 100.0 & 146.6 & 112 \\
\hline $197-06 / 2$ & 141.6 & 186.1 & 86.1 & 150.0 & 100.0 & 132.8 & 102 \\
\hline $197-06$ & 111.1 & 194.4 & 47.2 & 158.3 & 79.2 & 118.0 & 90 \\
\hline $197-06 / 1$ & 158.3 & 47.7 & 33.3 & 104.1 & 175.0 & 103.7 & 79 \\
\hline $225-11$ & 115.2 & 65.2 & 38.8 & 125.0 & 83.3 & 85.5 & 66 \\
\hline $27-86$ (st) & 130.5 & 50.0 & 37.5 & 93.0 & 104.2 & 83.0 & 64 \\
\hline $27-86(b)$ & 122.2 & 156.1 & 79.1 & 166.6 & 108.3 & 126.5 & 97 \\
\hline $27-86(f)$ & 75.0 & 127.7 & 55.5 & 105.5 & 175.0 & 107.7 & 83 \\
\hline $213-11 / 2$ & 184.7 & 98.6 & 55.5 & 150.0 & 50.0 & 107.8 & 83 \\
\hline $213-11$ & 205.5 & 141.6 & 52.7 & 134.7 & 87.5 & 124.4 & 95 \\
\hline $213-11 / 1$ & 233.3 & 188.8 & 80.5 & 186.1 & 108.3 & 159.4 & 122 \\
\hline Population VS-08 (st) & 151.3 & 187.5 & 61.1 & 134.7 & 95.8 & 126.1 & 97 \\
\hline Population VS-08 (b) & 76.1 & 163.8 & 65.2 & 161.1 & 97.9 & 112.8 & 87 \\
\hline Population VS-08 (f) & 204.1 & 245.8 & 41.6 & 160.2 & 104.2 & 151.2 & 116 \\
\hline $199-06 / 1$ & 216.6 & 248.6 & 40.9 & 195.1 & 77.7 & 155.8 & 119 \\
\hline NSR05 & 13.08 & 14.23 & 4.74 & 14.10 & 11.48 & & \\
\hline
\end{tabular}

Note: - * alfalfa was not harvested in 2014 due to the snow cover setting up in October.

In 2015 , for the fifth year of use, the yield of seeds in the breeding nursery was $30.5-80.5 \mathrm{~g} / 10 \mathrm{~m}^{2}$.

For the sixth year of life (2016), the yield of seeds was $84.7-248.6 \mathrm{~g} / 10 \mathrm{~m}^{2}$. Reliable excess over Uralochka standard was provided by numbers: $20-89 \mathrm{~N}$ (st) (by $40 \%$ ), 204-06/1 (67.7\%), 199-06/2 (by 98.8\%).

In the breeding nursery of alfalfa sown in 2011 (the ninth year of life) it was decided to conduct plots thrashing, plant formation condition - very good, the exception was two tiers (I and II) -due to high acidity of this site single plants remained, and also tires III and IV were under oppression (but partially), therefore harvest on this site was carried out selectively.

The results were obtained as follows: seeds yield of breeding numbers in 2019 amounted to $50.0-333.3 \mathrm{~g}$ from 10 $\mathrm{m}^{2}$. The highest yield was noted in numbers: $20-89 \mathrm{~N}$ (st), 20306, 197-06/1, 27-86 (f), 199-06/1, 101-2 (st), 20-89N (st).

On average for five years (on the 2nd, 3rd, 5th, 6th and 9th years of life) in breeding nursery seed yield amounted to 83.0$210.0 \mathrm{~g}$ from $10 \mathrm{~m}^{2}$. The following numbers have reliably exceeded the standard (Uralochka): Population VS-08 (f) $151.2 \mathrm{~g} / 10 \mathrm{~m}^{2}$ (by 16\%), 199-06/1 - $155.8 \mathrm{~g} / 10 \mathrm{~m}^{2}$ (by $19.6 \%$ ), $213-11 / 1-159.4 \mathrm{~g} / 10 \mathrm{~m}^{2}$ (by $22.3 \%$ ), 199-06/1 $210.0 \mathrm{~g} / 10 \mathrm{~m}^{2}$ (by $61.2 \%$ ).

The obtained experimental data testify to the prospects of research and confirm the high seed productivity of the lines created.

It is established that higher yields of seeds are given by those forms that are less demanding to warmth.
The yield of green mass in the breeding nursery (sowing 2015) in 2017 for the third year of use in the amount of two crops amounted to $6.7-28.5 \mathrm{~kg} / 10 \mathrm{~m}^{2}$. At the same time, it should be noted that for all the years of testing the higher yield of green mass is noted in the first harvest. Table 2 presents promising samples of breeding nursery, which exceeded the standard (Sarga) in three years. In the first mowing in 2017 the highest result in green mass yield was noted in samples: 199$06 / 1-20.8 \mathrm{~kg} / 10 \mathrm{~m}^{2}, 213-11-20.0 \mathrm{~kg} / 10 \mathrm{~m}^{2}$. (table 2). In the second mowing for the third year of life the significant excess to the standard was noted in the following numbers Victoria - $9.3 \mathrm{~kg} / 10 \mathrm{~m}^{2}, 213-11-8.2 \mathrm{~kg} / 10 \mathrm{~m}^{2}$.

For the fourth year of life, the yield of green mass was 5.0 $-20.0 \mathrm{~kg} / 10 \mathrm{~m}^{2}$. For the season of 2018 , the highest result in green mass yield was noted in the samples: Victoria -16.6 $\left.\mathrm{kg} / 10 \mathrm{~m}^{2}, 199-06-20.0 \mathrm{~kg} / 10 \mathrm{~m}^{2}(+3.34 \mathrm{~kg} / 10 \mathrm{~m})^{2}\right)$.

In 2019 , the green mass yield in the breeding nursery (sowing 2015) for the fifth year of life in the first crop of numbers have ranged from 0.8 to $7.5 \mathrm{~kg}$ from $10 \mathrm{~m}^{2}$. According to this indicator there following numbers stood out: Uralochka (f) - $6.6 \mathrm{~kg} / 10 \mathrm{~m}^{2}$, Victoria $-7.5 \mathrm{~kg} / 10 \mathrm{~m}^{2}, 199$ $06-5.8 \mathrm{~kg} / 10 \mathrm{~m}^{2}$.

In the second mowing, the yield of green mass was from 2.5 to $7.5 \mathrm{~kg}$ from $10 \mathrm{~m}^{2}$. The yield of green mass in the second mowing should be noted for numbers: Victoria -7.5 $\mathrm{kg} / 10 \mathrm{~m}^{2}, 199-06-6.6 \mathrm{~kg} / 10 \mathrm{~m}^{2}$. In sum for two crops the yield of green mass was $3.3-15.0 \mathrm{~kg} / 10 \mathrm{~m}^{2}$. 
For the season 2019, in the green mass yield the highest result was noted in the samples: Victoria $-15.0 \mathrm{~kg} / 10 \mathrm{~m}^{2}$, $199-06-12.4 \mathrm{~kg} / 10 \mathrm{~m}^{2}$, Uralochka (f) $-12.4 \mathrm{~kg} / 10 \mathrm{~m}^{2}$.

The yield of green mass on average for three years (2017-2019) was $5.0-20.1 \mathrm{~kg} / 10 \mathrm{~m}^{2}$. According to this indicator samples significantly exceeding the standard were: Victoria - by $20.4 \%, 213-11-5.1 \%, 199-06-15.0 \%$.

Table 2. Green mass yield of alfalfa variable in breeding nursery, $\mathrm{kg}$ from $10 \mathrm{~m}^{2}$ (sowing 2015, accounting 2017-2019)

\begin{tabular}{|c|c|c|c|c|c|c|c|c|c|c|}
\hline \multirow[t]{3}{*}{ Genotype } & \multicolumn{5}{|c|}{ First mowing } & \multicolumn{5}{|c|}{ Second mowing } \\
\hline & \multicolumn{3}{|c|}{ year of life } & \multirow{2}{*}{$\overline{\mathrm{x}}$} & \multirow[t]{2}{*}{$\%$ to $\mathrm{st}$} & \multicolumn{3}{|c|}{ year of life } & \multirow{2}{*}{$\overline{\mathrm{x}}$} & \multirow[t]{2}{*}{$\%$ to $\mathrm{st}$} \\
\hline & $3 \mathrm{rd}$ & 4 th & 5 th & & & $3 \mathrm{rd}$ & 4th & 5th & & \\
\hline Sarga - st. & 16.7 & 10.8 & 4.1 & 10.5 & 100 & 7.5 & 5.8 & 5.0 & 6.1 & 100 \\
\hline Victoria & 19.2 & 10.8 & 7.5 & 12.5 & 119 & 9.3 & 5.8 & 7.5 & 7.5 & 123 \\
\hline $213-11$ & 20.0 & 10.0 & 4.1 & 11.4 & 109 & 8.2 & 6.3 & 4.1 & 6.2 & 102 \\
\hline $199-06 / 1$ & 20.8 & 11.7 & 3.3 & 11.9 & 113 & 6.7 & 4.2 & 4.1 & 5.0 & 82 \\
\hline $199-06$ & 17.5 & 12.5 & 5.8 & 11.9 & 113 & 7.7 & 7.5 & 6.6 & 7.3 & 120 \\
\hline Uralochka (f) & 16.7 & 9.2 & 6.6 & 10.8 & 103 & 7.3 & 5.8 & 5.8 & 6.3 & 103 \\
\hline NSR05 & 1.8 & 0.9 & 0.4 & & & 0.7 & 0.5 & 0.5 & & \\
\hline
\end{tabular}

The dry matter collection for the third year of life amounted to $1.04-4.85 \mathrm{~kg} / 10 \mathrm{~m}^{2}$ in the first mowing (standard - $\left.3.59 \mathrm{~kg} / 10 \mathrm{~m}^{2}\right)$. The highest yield was shown by number $199-06 / 1$ (table 3 ). In the second mowing the yield was 0.40 $1.91 \mathrm{~kg} / 10 \mathrm{~m}^{2}$, Victoria should be noted $-9.3 \mathrm{~kg} / 10 \mathrm{~m}^{2}(+1.8$ $\left.\mathrm{kg} / 10 \mathrm{~m}^{2}\right), 213-11-8.2\left(+0.7 \mathrm{~kg} / 10 \mathrm{~m}^{2}\right)$.

In the second year of use, the dry matter collection was $9.16-20.0 \mathrm{~kg} / 10 \mathrm{~m}^{2}$ (standard - $\left.16.66 \mathrm{~kg} / 10 \mathrm{~m}^{2}\right)$.
According to this indicator the standard number's exceeding in the first mowing was: $199-06-3.01 \mathrm{~kg} / 10 \mathrm{~m}^{2}$ $(+14.8 \%)$, in the second mowing $-213-11-1.68 \mathrm{~kg} / 10 \mathrm{~m}^{2}$ $(+38.8 \%$ to the standard)

In 2019 , the dry matter harvest was $0.69-3.28 \mathrm{~kg} / 10 \mathrm{~m}^{2}$ (standard $2.28 \mathrm{~kg} / 10 \mathrm{~m}^{2}$ ). The highest yield of dry matter was noted in the first mowing of Uralochka (f) $-2.02 \mathrm{~kg} / 10 \mathrm{~m}^{2}$ $(+64.2 \%$ to the standard $)$.

Table 3. Yield of air-dry weight of alfalfa variable in breeding nursery, $\mathrm{kg}$ from $10 \mathrm{~m}^{2}$, (sowing 2015, accounting 2017-2019)

\begin{tabular}{|c|c|c|c|c|c|c|c|c|c|c|}
\hline \multirow[t]{3}{*}{ Genotype } & \multicolumn{5}{|c|}{ First mowing } & \multicolumn{5}{|c|}{ Second mowing } \\
\hline & \multicolumn{3}{|c|}{ year of life } & - & \multirow[t]{2}{*}{$\%$ to st } & \multicolumn{3}{|c|}{ year of life } & \multirow{2}{*}{$\begin{array}{l}- \\
\mathrm{x}\end{array}$} & \multirow[t]{2}{*}{$\%$ to st } \\
\hline & $3 \mathrm{rd}$ & 4th & 5 th & & & $3 \mathrm{rd}$ & 4th & 5 th & & \\
\hline Sarga - st. & 3.59 & 2.62 & 1.23 & 2.48 & 100 & 1.64 & 1.21 & 1.05 & 1.30 & 100 \\
\hline Victoria & 3.11 & 2.45 & 1.93 & 2.50 & 101 & 1.91 & 1.24 & 1.35 & 1.50 & 115 \\
\hline $213-11$ & 4.58 & 2.29 & 1.17 & 2.68 & 108 & 1.72 & 1.68 & 0.84 & 1.41 & 108 \\
\hline $199-06 / 1$ & 4.85 & 2.35 & 0.85 & 2.68 & 108 & 1.46 & 1.02 & 0.69 & 1.06 & 82 \\
\hline 199-06 & 3.52 & 3.01 & 1.58 & 2.70 & 109 & 1.68 & 1.65 & 1.38 & 1.57 & 121 \\
\hline Uralochka (f) & 3.57 & 2.16 & 2.02 & 2.58 & 104 & 1.59 & 1.28 & 1.24 & 1.37 & 105 \\
\hline $\mathrm{NSR}_{05}$ & 0.35 & 0.22 & 0.13 & & & 0.15 & 0.12 & 0.10 & & \\
\hline
\end{tabular}

Based on the results of three years of study, the average dry matter collected was $1.08-4.27 \mathrm{~kg} / 10 \mathrm{~m}^{2}$ (standard 3.78 $\mathrm{kg} / 10 \mathrm{~m}^{2}$ ), exceeding by $4.5-13.0 \%$. Significant additions to the standard are noted for numbers: 213-11, 199-06, collecting dry matter at which reached 4.09-4.27 t/ha.

The seeds yield in the breeding nursery of alfalfa (sowing 2015) for these numbers in 2016 was 11.3-113.9 $\mathrm{g}$ from 10 $\mathrm{m}^{2}$. The highest yield was noted in the numbers: Uralochka (b) $-113.9 \mathrm{~g} / 10 \mathrm{~m}^{2}, 101-2$ (f) $-86.1 \mathrm{~g} / 10 \mathrm{~m}^{2}, 213-11-78.1$ $\mathrm{g} / 10 \mathrm{~m}^{2}$ (table 4).

In 2017, during the alfalfa flowering period, the beginning of flowering phase was recorded on July $04-07$, later than the average annual data. Adverse weather conditions caused the formation of low seeds yield in most numbers of alfalfa.
The seeds yield in the breeding nursery of alfalfa (sowing 2015) in 2017 for the third year of life of the numbers amounted to $27.5-120.8 \mathrm{~g}$ from $10 \mathrm{~m}^{2}$. The highest yield was noted for numbers: CHP $-1(\mathrm{~g})-150.0 \mathrm{~g} / 10 \mathrm{~m}^{2}, 192-92$ (f) $-133.3 \mathrm{~g} / 10 \mathrm{~m}^{2}, 213-11-78.1 \mathrm{~g} / 10 \mathrm{~m}^{2}, 199-06 / 1-120.8$ $\mathrm{g} / 10 \mathrm{~m}^{2}, 213-11 / 1-118.8 \mathrm{~g} / 10 \mathrm{~m}^{2}$.

The seeds yield in the breeding nursery of alfalfa (sowing 2015) in 2018 for the fourth year of life of the numbers amounted to 50.0-195.8 g with $10 \mathrm{~m}^{2}$. Reliable excess of the seeds yield was noted in numbers: CHP $-1(\mathrm{~g})-104 \%$, CHP -3 (b) $-50 \%$, Victoria $-60 \%, 192-92$ (f) $-58 \%$.

The seeds yield in the breeding nursery of alfalfa (sowing 2015) in 2019 for the fifth year of life of the numbers 
amounted to $62.5-220.8 \mathrm{~g}$ from $10 \mathrm{~m}^{2}$. Reliable excess of the seeds yield was noted for all numbers in the breeding nursery.

Table 4. Seeds yield of alfalfa variable in breeding nursery, g from $10 \mathrm{~m}^{2}$, (sowing 2015, accounting 2016-2019)

\begin{tabular}{|c|c|c|c|c|c|c|}
\hline \multirow[t]{2}{*}{ Grade, sample } & \multicolumn{4}{|c|}{ Year of life } & \multirow{2}{*}{$\overline{\mathrm{X}}$} & \multirow[t]{2}{*}{$\%$ to $\mathrm{s}$} \\
\hline & 2nd & $3 \mathrm{rd}$ & 4th & 5 th & & \\
\hline Sarga - st. & 77.8 & 39.6 & 95.8 & 62.5 & 68.9 & 100 \\
\hline Victoria & 68.3 & 104.2 & 153.3 & 141.6 & 116.9 & 170 \\
\hline CHP-1 (g) & 41.7 & 150.0 & 195.8 & 120.8 & 127.1 & 184 \\
\hline $192-92$ (f) & 11.3 & 133.3 & 151.2 & 91.6 & 96.9 & 141 \\
\hline $30-1(\mathrm{st})$ & 36.1 & 62.5 & 112.5 & 108.3 & 79.9 & 116 \\
\hline $20-89 \mathrm{~N}(\mathrm{~b})$ & 30.0 & 63.8 & 106.2 & 141.6 & 85.4 & 124 \\
\hline $199-06 / 2$ & 15.7 & 84.2 & 131.7 & 133.3 & 91.2 & 132 \\
\hline 213-11 & 78.1 & 55.0 & 125.0 & 220.8 & 119.7 & 174 \\
\hline $213-11 / 1$ & 37.5 & 116.7 & 113.3 & 102.1 & 92.4 & 134 \\
\hline $199-06 / 1$ & 20.6 & 120.8 & 128.3 & 100.0 & 92.4 & 134 \\
\hline CHP-2 (p) & 50.0 & 94.6 & 87.5 & 110.4 & 85.6 & 124 \\
\hline $193-95$ (f) & 30.3 & 75.0 & 104.2 & 131.3 & 85.2 & 124 \\
\hline $20-89 \mathrm{~N}(\mathrm{f})$ & 16.8 & 83.3 & 93.7 & 133.3 & 81.8 & 119 \\
\hline $101-2(f)$ & 86.1 & 68.8 & 85.4 & 127.1 & 91.9 & 133 \\
\hline $203-06 / 2$ & 63.9 & 50.0 & 65.0 & 112.5 & 72.9 & 106 \\
\hline $204-06 / 2$ & 88.9 & 66.6 & 77.1 & 114.6 & 86.8 & 126 \\
\hline Uralochka (st) & 34.2 & 69.6 & 83.3 & 100.0 & 71.8 & 104 \\
\hline Uralochka (b) & 113.9 & 47.9 & 91.7 & 125.0 & 94.6 & 137 \\
\hline Uralochka (f) & 61.1 & 27.5 & 112.5 & 100.0 & 75.3 & 109 \\
\hline $197-06$ & 14.0 & 79.2 & 104.2 & 110.4 & 77.0 & 112 \\
\hline $213-11 / 2$ & 25.6 & 118.8 & 62.5 & 175.0 & 95.5 & 138 \\
\hline population (st) & 52.2 & 83.3 & 75.0 & 125.0 & 83.9 & 122 \\
\hline population (f) & 52.8 & 70.0 & 87.5 & 139.6 & 87.5 & 127 \\
\hline CHP-3 (b) & 36.7 & 75.0 & 143.7 & 145.8 & 100.3 & 146 \\
\hline $20-89 \mathrm{~N}(\mathrm{st})$ & 34.7 & 74.2 & 50.0 & 137.5 & 74.1 & 108 \\
\hline $101-2(\mathrm{st})$ & 25.6 & 46.7 & 70.8 & 137.5 & 70.2 & 102 \\
\hline $203-06$ & 55.6 & 45.8 & 80.8 & 129.2 & 77.9 & 113 \\
\hline NSR05 & 4.37 & 7.09 & 9.44 & 11.49 & & \\
\hline
\end{tabular}

In breeding nursery (sowing 2015) on average for four years (2016-2019) the yield amounted to 59.4 - $127.1 \mathrm{~g} / 10$ $\mathrm{m}^{2}$. Reliable excess above the Sarga standard was obtained for the following samples: Victoria $-70 \%$, CHP-1 (g) - 85\%, 192-92 (f) - 41\%, 199-06/1-34\%.

The obtained promising numbers will be included in the nursery of the competitive test.

\section{CONCLUSIONS}

On average for three years in the breeding nursery the seeds yield significantly exceeded the standard of varieties and numbers: Victoria - by $70 \%$, CHP-1 - by $84 \%$, CHP-2 24\%, 192-92 (f) - by 41\%, 213-11 - 74\%. The average yield of green mass for three years was 5.0-20.1 kg/10 m². According to this indicator the following samples significantly exceed the standard: Victoria - by $20.4 \%, 213-11-5.1 \%$, $199-06-15.0 \%$. Dry matter collection was $1.08-4.27 \mathrm{~kg} / 10$ $\mathrm{m}^{2}$ (standard $3.78 \mathrm{~kg} / 10 \mathrm{~m}^{2}$ ), excess of $4.5-13.0 \%$.

Experimental data on the longevity of alfalfa confirm the prospect of increasing seed productivity in the created selffertile lines.

\section{ACKNOWLEDGMENT}

This work was supported by the Ural Federal Agrarian Scientific Research Center.

\section{References}

[1] R. Mouttet, A. Escobar-Gutiérrez, M. Esquibet, L. Gentzbittel, D. Mugniéry, P. Reignault, C. Sarniguet and P. Castagnone-Sereno, "Banning of methyl bromide for seed treatment: could Ditylenchus dipsaci again become a major threat to M. sativa production in Europe" Pest management science. Vol. 70, 2014, pp. 1017-1022

[2] H. Z. Karimov "Alfalfa for seeds in Kazakhstan" / H. Z. Karimov, R. R. Gareyev, O. L. Shaytanov, Center of operational printing, 2003, pp. 103.

[3] Y. M. Piskovatsky, V. M. Kosolapov, V. E. Mikhalev, G. V. Stepanova, N. I. Pereravo, L. F. Solozhentseva, M. G. Lomova, "Agrotechnics of varieties cultivation of alfalfa breeding by All-Russian Scientific Research Institute of fodder named after V. P. Williams for seed 
and feed purposes". (Recommendations). M.: Federal Budgetary Institution, Russian Center of Agricultural Consulting, 2008, pp. 39.

[4] S. Song, P. Walton "Combining ability, genotype environment interactions and genotypes correlations of agronomic characters in Medicago sativa L.", Euphycia. - 24, N 2, 1975, pp. 471-481.

[5] I. K. Tkachenko, N. A. Surkov, V. I. Chernyavskikh, K. A. Ionov, E. V. Dumacheva, "Breeding and seed production of alfalfa and other herbs" Belgorod: "Peasant business", 2005. pp. 392

[6] V. M. Pomogaibo "Road analysis of productivity components of blue-hybrid alfalfa", Genetics. no. 8. 1981. pp. 1473-1478.

[7] A. A. Zhuchenko, "Adaptive cultivation: ecological and genetic basis", Saratov, 2012. pp. 528

[8] V. M. Kosolapov, N. N. Kozlov, A. I. Klimenko, "Ecological selection of perennial forage grass", Fodder production. No.4, 2015, pp. 25-28.

[9] V. M. Kosolapov, "Selection of feed crops and food security of Russia: problems and ways of solving" Fodder production. No. 9, 2012, pp. 24-26.

[10] V. M. Pomogaibo "Connection of some morphological traits with productivity of alfalfa plants", Reports of the All-Union Academy of Agricultural Sciences named after V.I.Lenin. No. 2. 1982. pp. 23-24.

[11] T. V. Radchenko, "Selection efficiency on seed productivity of alfalfa" Genetic bases of grain, legumes, cereals, technical fodder, vegetable and perennial crops. Kiev, Ch. Z. 1986, pp. 179

[12] O. Chloupek et al. "Hodnoceni nadzemnich casti a korenu vojetesky pri castych secich", Sb UVTIZ. Genet. A Slecht. 21, N 1. 1985, pp. 61-70.

[13] "Methods of the State Commission on variety testing of agricultural crops", M., 1985, pp. 267.

[14] B. A. Dospekhov, "Methodology of field experience (with the basics of statistical processing of research results)".5th ed., added and revised. M.: Agropromizdat, 1985, pp. 351, pic. (Textbooks and manuals for higher educational institutions).

[15] Z. S. Shamsutdinov, Y. M. Piskovatsky, M. Y. Novoselov, Y. S. Tyurin et al., "Results and priorities in breeding of fodder plants", Feed production: problems and solutions: collection of scientific papers M.: Federal State National University "Rosinformagroteh", 2007, pp. 241-257.

[16] N. N. Lazarev, S. M. Avdeev, L. Y. Demina, V. G. Yatskova, "Change of agrochemical properties of sodpodzolic soil and yield of legumes and legum-cereal grass at their long-term use", Bulletin of the Moscow Agrarian Academy, Issue 1, 2011, pp. 11-15.

[17] N. N. Lazarev, A. N. Isakov, A. M. Starodubtseva, "Meadow herbs in the Non-Chernozem region: yield, longevity, nutrient value", M.: Publishing house of the Moscow Agrarian Academy named after K.A. Timiryazev, 2015. pp. 218

[18] W. M. Canevari, "Overseeding and companion cropping in alfalfa", University of California, Division of Agriculture, 2000, pp. 31.
[19] J. J. Volenec, J. H. Cherney, K. D. Johnson, "Yield components, plant morphology, and forage quality of alfalfa as infl uenced by plant population", Crop Sci. Vol. 1987, Pp. 321-326.

[20] M. W. Pedersen, W. P. Nye, "Alfalfa seed production studies", Utach Status and U.S. Dept. Agr. Exp. St. Bull. 1962, N 436.

[21] N. N. Dyukova, Yu. P. Loginov, N. V. Shadrina, "Substantiation of alfalfa variety model parameters for the North TranS-Urals' conditions", Agrarian bulletin of the Urals, № 9 (115), 2013, pp. 9-11.

[22] A. E. Nagibin, M. A. Tormozin, A. A. Zyryantseva, "Breeding work with alfalfa in the Middle Urals", Agrarian bulletin of the Urals, № 7 (137), 2015. pp. 2024.

\section{Creative Commons Attribution License 4.0 (Attribution 4.0 International, CC BY 4.0)}

This article is published under the terms of the Creative Commons Attribution License 4.0

https://creativecommons.org/licenses/by/4.0/deed.en_US 